\title{
Blended Learning at the Faculty of Business in Al-Balqa Applied University
}

\author{
Khalil Al-Hyari ${ }^{1}$ \\ ${ }^{1}$ Faculty of Business, Al-Balqa Applied University, Jordan \\ Correspondence: Khalil Al-Hyari, Faculty of Business, Al-Balqa Applied University, Jordan. E-mail: \\ kalhyari@bau.edu.jo
}

Received: August 9, 2020

Accepted: September 10, 2020

Online Published: September 16, 2020

doi:10.5539/ijbm.v15n10p14

URL: https://doi.org/10.5539/ijbm.v15n10p14

\begin{abstract}
The purpose of this study is to explore student and lecturer views of blended learning which is based upon an undergraduate courses offered at the faculty of business at Al-Balqa Applied University, which applied the blended learning approach based on the use of face to face F2F, and e-learning. The study is based on the exploratory qualitative research approach, specifically designed to identify students and lecturers' perceptions towards blended learning process, content, and ease of use. The case study data were collected through structured interviews with 40 undergraduate students who were enrolled in different courses and from 10 lecturers from the faculty of business at Al-Balqa Applied University. In comparison to the traditional face-to-face (F2F) approach, both students and lecturers found the blended learning method more flexible and preferred it over F2F in many instances. The study concludes that in general, the lectures/students' attitudes towards BL were positive in terms of the domain process, and content. Moreover, they believe that blended learning applications are, hardly, challenging to be applied sometimes. The study also presents that, in order for graduates to meet the challenges of entering the workforce of the 21 st century, blended learning should be used as a new learning strategy. Findings of this study will be beneficial for policy makers to formulate appropriate and effective policy to assist the higher education institutions. Also this study is important for university students and lecturers, as it makes them very aware of the significance of blended learning and transferable skills in the workplace. This study provides fresh insights into the context of the benefits of blended learning in Middle East, particularly in Jordan. Moreover, the higher learning institution will be capable to determine the blended learning satisfaction level amongst students and lecturers.
\end{abstract}

Keywords: universities, students /lecturers' perceptions, blended learning, teaching methods, faculty of business, Jordan

\section{Introduction}

Fast and effective improvements in today's technologies cause changes in all aspects of human life (Inal \& Korkmaz, 2019). Technology has an important role to play in building up 21st-century skills. Researchers have tried to understand the effectiveness of advance technologies in education context (Bayrak \& Akcam, 2017; Zhang, 2018), the advancement use of learning technologies, fundamentally the new information and communication technologies in the educational process have created blended learning approach (Shantakumari \& Sajith, 2015; Uğur et al., 2011).

Research into blended learning in management education has exploded since the early aughts of this century (Arbaugh et al., 2010). In fact, many universities, including Al-Balqa Applied University, have implemented blended learning (BL) in the form of e-learning as part of its learning system within the last decade, and many of these universities have gotten great results when they changed their traditional face-to-face learning or e-learning methods and applied several applications models of BL (Nguyen, 2017). Thus, those universities that are currently using virtual learning environments are proactively seeking other areas that can be improved through blended learning. For example, combining online learning with F2F teaching is an idea that many business students are becoming accustomed to (Fearon et al., 2011). As a result, BL has become a widespread learning method among higher learning institutions as its coordinates up close and personal instructing with online learning (Zainol, 2018).

It is imperative to conclude whether or not the rise in the use of both e-learning and blended learning methods 
has positively impacted the academic performance of students and lecturers and if this improved learning outcomes, as well (Wong et al., 2014). According to Saleem (2017), universities are currently looking to develop performance and discover knowledge through the planning and creation of specialized academic and training programs that are founded on the application of e-learning knowledge to improve learning in conventional classrooms.

Higher learning institutions, particularly those in developing countries, are resisting a full e-learning environment although it becomes a significant instrument to support the learning system to attain its objectives within learning process for numerous institutions around the world (Saadeh \& Al-Karimi, 2009). According to Al-Busaidi, (2013), particularly in Middle-East region, not much research has been conducted which has evaluated the impact that the learners' acceptance of blended learning to their full e-learning has had on developing countries. As well as Bunt-Kokhuis and Weir, (2013) mentioned that in many cases from the Arab world the easy online access to educational structures and knowledge is not available yet across their cultures. Therefore, this study adds to the development of appropriate educational approaches to BL content in developing countries in general and in Jordan in particular.

A blend of traditional methods face-to-face classroom teaching F2F which contain (explanation, discussion and dialogue), with technology-based instruction, including online communication throughout the internet, e-mail, electronic syllabus, entails significant changes to the course delivery. Taking into consideration the arguments above, in this study the definition of blended learning will be used which refers to an approach that mixes both traditional F2F learning and e-learning for the scope of this study. The goal of this study is to close this gap by looking at the perceptions and practices associated with blended learning in higher education and to identify factors that either help or hinder the adoption and execution of blended learning at the faculty of business at Al-Balqa Applied University. This study also tries to find the answers for the following research questions:

1. What are academic staff perceptions of blended learning?

2. What are students' perceptions of blended learning?

This paper starts by reviewing relevant literature, including an introduction to blended learning; the benefits and risks associates with blended learning; e-learning and blended learning; and the blended learning situation at the faculty of business summarizing the experience of BL initiative in Al-Balqa Applied University and its influence on the students. Afterwards, provides the theoretical framework for this study. This is followed by a discussion of the research methodology implemented; findings and discussion are then presented next. Then the conclusions and general recommendations drawn from this study. Finally, the limitations of the research are presented along with the recommendations for future research.

\section{Literature Review}

\subsection{Introduction to Blended Learning}

Advancement in science and technology in the current era ushered in many new teaching and learning approaches, such as e-learning and blended learning (Oweis, 2018). The idea of blended learning is garnering increased attention from in the education academia (Arbaugh et al., 2010; Benson et al., 2011; Almasi \& Zhu, 2018). Blended learning presents an efficient platform for the application of a variety of educational strategies in the digital age and has the potential of combining the best features of face-to-face and online learning support for a flexible method to overall learning and skills improvement (Fearon et al., 2011; Tso, 2015).

Advocates of blended learning propose that there must be a joint approach, more precisely, face-to-face interaction together with the adoption of online technology, in contradiction of the traditional educationalists who argue that, for lectures and seminars, a learner's physical attendance is necessary when it comes to face-to-face interaction (Fearon et al., 2011).

BL is a term that lacks a unified definition (Medina, 2018). There are numerous definitions in the literature. While defining what exactly founds a BL environment has been somewhat of a challenge (Arbaugh et al., 2010). A recent review of literature about BL showed that there are no two blended learning designs are alike; thus, it can be exemplified by a course where $20-79 \%$ of content is delivered online through a combination of face-to-face and online delivery (Al-Busaidi, 2013; Arbaugh et al., 2010). According Medina, (2018), BL restructure the way that courses are developed, scheduled, and delivered in higher education institutions thru a blend of physical and virtual methods.

In Jordan, the flexibility and reduction of time and cost are the main motivations for using blended learning with the availability of both synchronous and asynchronous e-learning options which may result in giant strides in the amount of productivity achieved by the student (Saadeh \& Al-Karimi, 2009; Obiedat et al., 2014). Recently, 
Al-Balqa Applied University adopted the BL approach, such system of learning is not a replacement for the traditional F2F approach; however, it can be used to develop the learning process at the university.

\subsection{Blended Learning: Benefits and Risks}

Blended learning has many benefits over traditional teaching methods; for example, some of the benefits are improved time efficiency, providing flexibility in terms of assignment submission, marking, assessment methods, and offering students the chance to fit multiple commitments within their schedules, and students are not restricted in gaining access to course's activities and material which enables them to choose to participate in the course from wherever and whenever they want, thereby increasing the quality and value of their education (Saadeh \& Al-Karimi, 2009; Benson et al., 2011; Tso, 2015). Moreover, this provides more flexibility than the conventional approach, as students can download learning materials at their convenience, regardless of time, location, or physical attendance at the classroom lecture, which will increase learner control of the educational experience, and permits students to take benefit of resources, not only at a technological level but also at a pedagogical one, namely in reference to community building and collaborative learning opportunities (Arbaugh et al., 2010; Fearon et al., 2011; Medina, 2018).

Student satisfaction is one of the issues that can be evaluated to conclude whether BL has been effective or not (Medina, 2018). According to Zainol, (2018), perceived ease of use, learning environment and student/lecturer interaction are having important influence to blended learning satisfaction among students. Moreover, a strong record of individual, group and collaborative blended learning skills should be acquired by business students before graduating from university (Fearon et al., (2012). For the academic staff, their choice to implement blended learning mainly depends on the resources available and their knowledge about them. Not all academic staff chooses to take advantage of them, despite the availability of many supporting resources, for example, they can acquire the necessary learning management systems, computerized assessment tools, wireless networks and other devices (Benson et al., 2011).

Although the literature approved of the benefits of blended learning and e-learning to enhance teaching and learning worldwide, there is a widely held perception that introducing computer components into a traditional F2F course does not necessarily develop the learning outcomes for business courses, since students expressed they preferred to use the face-to-face approach and they would only endorse internet usage that reinforced the conventional delivery of courses because they feel classroom environment provides more benefits to them by way of the social interaction and the communication skills they gain there, that means, students appreciate the convenience from online-learning but, simultaneously, they do not want to lose direct communication with their lectures (Lam et al., 2011; Thomas \& Thomas, 2012; Wong et al., 2014; Poon, Joanna, 2012).

A number of studies about the costs and benefits of e-learning and blended learning in Jordan have been carried out. For example, Saadeh and Al-Karimi, (2009), Obiedat et al., (2014), and Oweis, (2018) found that the communication between a student and a lecturer does not occur simultaneously, because students and lecturers cannot $\log$ on to the system simultaneously and communicate either directly or virtually with one another. Yet other concerns are that the students' knowledge regarding the use of technology may not be as high as expected, there may be technical difficulties including poor internet connectivity and high maintenance cost, and there may be inadequate technical accessibility resulting in wasted resources.

\subsection{E-Learning and Blended Learning}

The growing roles of advance technology in the learning field motivate researchers to understand the usefulness of such technologies in education framework. Computers, computer networks, projectors, smart boards as an example of such technologies are often employed in the form of e-learning to improve classroom activities (Bayrak \& Akcam, 2017; Perera et al., 2017). All of these tools improve the student learning experience and enhance student engagement, in addition to improving the course administration and management all through the use of information and communication technologies (Tso, 2015).

E-learning takes many approaches, the two main one are the fully online, and blended learning. The e-learning approach overcomes several disadvantages that are characteristic of traditional to F2F classroom teaching, chiefly its lack of flexibility in the use of resources. Nevertheless, there is no perception of cultural sensitivity in the online classroom like that presented in physical classrooms enabling lecturers and students to be culturally sensitive in physical classrooms are missing in the online world. Taking into consideration the discussion above, it has been suggested that students and lecturers use BL which combines the conveniences of both online and face-to-face instruction which will enhance the students' and lecturers' academic performance (Bentley et al., 2012; Alkış \& Temizel, 2018). 
According to Saadeh and Al-Karimi, (2009), e-learning contains three approaches: The first one is an enhanced approach used to support, and facilitate the F2F learning approach by using online technology. The second one is the blended approach where the substantial portion of content is delivered online by mixing traditional F2F with online learning. The third one is the online approach which uses virtual learning which is accomplished without the need for F2F student and lecturer meetings.

Therefore, since it provides participants access to socialization with other trainees and allows greater flexibility to training professionals in organizing training sessions as well as the use of different tools such as virtual classrooms and interactive TV, blended learning is a great response to the restrictions presented by e-learning (Oiry, 2009). Additionally, Magnier-Watanabe et al., (2011), recommend developing and managing hybrid courses, or blended learning, that would harmonize the positive characteristics of e-learning with the benefits of face-to-face instruction.

\section{Theoretical Framework}

Recognizing the success elements behind the use of technologies in educational institutions, particularly, the universities have been a significant objective of researchers. For example, the framework of information systems success model focuses on the correlation between user attitude, IT, and net benefits to institutions and individuals. Further, the technology acceptance model frameworks focus on user acceptance and satisfaction (Bayrak \& Akcam, 2017). The essential factor for the success of blended learning is Lecturers/Students' satisfaction.

Assessment of the success of BL courses mainly depend on students' expectations, attitudes, and their satisfaction, since their feedback is important to guarantee a successful implementation of any teaching learning approach (Shantakumari \& Sajith, 2015). According to Bayrak and Akcam, (2017), the effectiveness of the technology learning environment from a pure end-user depends on their satisfaction perspective toward content, accuracy, format, ease of use, and timeliness. Many researchers concentrated on Lecturers/students' satisfaction towards blended learning in general. Uğur et al., (2011) are one of those who clarify positive students' views on blended learning method to asses efficiency and effectiveness of a learning environment. Students' views can be influenced by some elements for example, their learning styles, self-efficacy, attitudes, motivations and interests.

To determine the students' perceptions toward BL which in turn will determine their satisfaction of the courses offered. Shantakumari and Sajith, (2015) conducted a study at the Gulf Medical University in Ajman/UAE, which offers a number of courses integrate BL with contact classes and online component on an e-learning approach. They found that students hold a positive perception of the BL courses being offered in this university, and they suggested that BL format needs adaptation in line with course content to enhance its perception.

In the same way, Hussin et al., (2009) in their study about examining learners' perspective in Malaysian institution of higher learning, they developed an effective instructional design for e-learning which included many elements. Firstly, the content element includes all the conceivable materials that the learners may need and in different forms. The second element is the interaction design. Third, the feedback which is the most frequently mentioned concern of online learners. Finally, the interface design, the effectiveness of e-learning strategies depended on a proper interface design to allow trouble free and easy access to those features by students.

According to Nortvig et al. (2018), blended learning enhances the presence of the lecturer and strengthens the relationship between the lecturer and the students and among the students themselves. This would have a positive impact on students' learning and would help in building learning communities. They also recommend that BL has to be designed in a way that the activities and content have to be parallel and coherent.

Aristovnik et al., (2016) are one of the researchers who studied the factors influencing the learners' successes in the e-course, for instance interaction between student/student or teacher/ student in the e-course, the spends time in the e-course by the students, frequency accesses of the e-course, and late submissions. Such aspects might influence the value of blended learning throughout the students' perception. Their results showed that the consciousness about the e-courses, their consistency with the F2F teaching approach and the teachers' responsiveness had an important influence on the students' perception of the usefulness of e-courses. Kintu et al., (2017), similarly in their study about the effectiveness of blended learning, found that some of the student characteristics/backgrounds and design features are important predictors for student learning outcomes in blended learning.

According to Poon, Joanna, (2012) the successful factors for blended learning implementation in different organizations from the opinion of the academics' delivery of their subject required a variety of support resources, such as, the skills training, technological requirements, human factors, and the allocation of dedicated services to 
support learners and facilitators during the improvement and use of modules. Inal and Korkmaz, (2019) in their study about the effect of web based blended learning on academic achievement, they developed a framework which consisted of five factors namely, sensitivity, consciousness, significance, method and materials, and language and culture. They found that BL contributes significantly to the academic achievement compared to the traditional approach in teaching.

As well, Cundell and Sheepy, (2018) in their study about student perceptions of the most effective and engaging online learning activities in a blended course, the participants evaluated the course according to ease of navigation, clarity of expectations and instructions, accessibility of materials, instructor presence, and technical quality of media. Wong et al., (2014) proposed a theoretical framework for investigating blended learning effectiveness based on the modified model of OECD for blended learning to assess the readiness, considering institution readiness, staff readiness and student readiness. In addition to the intensity of adoption, which considers the blended learning options chosen for adoption via staff and students. Finally, impact or quality of learning achieved. Also, Shantakumari and Sajith, (2015) and Adas and Wafa (2011), found in their study that the students' attitudes toward Blended Learning were positive in terms of the process, ease of use and content. Once institutions and instructors have adopted a variety of choices as part of their blended learning suite, it is then students' readiness that influences their intensity of adoption which will impact on their learning. Therefore, the quality of learning achieved as an impact of blended learning will assess through some measurement such as, overall performance, and assessments of satisfaction.

The feedback of lecturers/students who are among the key stakeholders is absolutely important to guarantee a successful implementation of any teaching learning approach. Failure to appreciate the views of them could result in the lowering of their satisfaction. This study was conducted with an aim of determining lecturers'/students' perception of BL courses according to their process, content, and ease of use to ensure that prompt corrections can be made to the entire system based on the research results. These studies contribute greatly to the discussion of blended learning on the development and identification of successful features for blended learning from the point of view of the lecturers and students in terms of the process, content, and ease of use of blended learning approach in the faculty of business at Al-Balqa Applied University. This study is, therefore, of paramount significance as the faculty moves towards changing its delivery method to contain a module of online delivery.

\section{Research Design and Methodology}

The present study uses qualitative exploratory research based primarily on structured interviews. Qualitative exploratory research methodology is associated to a phenomenon about which there is no sufficient knowledge and is considered to be suitable for when the researcher studies a new field of research or plans to find and hypothesize prominent subjects, and unravels a complex set of elements and relationships for theory development, whether in one or a small number of instances (Yin, 2018; Sekaran \& Bougie, 2016). The trends being studied are not very well understood, and their scope and logic are doubtful. Consequently, a case-study methodology was used to helped author to provide a deeper understanding of academic staff and students views towards blended learning and current blended learning practices. According to Benson et al., (2011), a case-study methodology was implemented in their research to determine academic staff views towards blended learning and contemporary blended learning practices.

Neira et al., (2017) found that the most used methodology about emerging technologies in education between 2006 and 2016 was qualitative research. Many scholars state that a qualitative research could be conducted on a small sample, such as Dana and Dana (2005); Benson et al., (2011) rather than having a large sample. In such cases the internal validity could be achieved, but the external validity would be somehow limited. This limitation could be justified by stating that local or regional research contributes to local or regional theories. In such cases, "global generaliseability to other populations or cultures is not applicable or desirable" (Dana \& Dana, 2005, p. $84)$.

The data was collected using a structured interviews based on check-list of questions prepared after looking critically at the literature review related to this field. The interview check-list was evaluated by some experts specialized from different faculties at Al-Balqa Applied University in order to ensure its validity and reliability. A pilot study was also conducted with three students. Minor comments were provided by the lecturers/students about some of the questions in the interview's check-list. These comments resulted in a suitable adaptation of the questions in a way that is more appropriate to the aim of the study. Confidentiality was protected, as no personal identifying detail was collected in the interview. In addition, to achieve content validity, the research included validated questions used from (Shantakumari \& Sajith, 2015; Ja'ashan, 2015; Adas \& Wafa, 2011). 
The justifications of using structured interview, that it uses a standardized questioning and scoring process for all candidates, and all candidates are asked the same predetermined questions and in the same order (Sekaran \& Bougie, 2016). Another justification is that, all responses are evaluated using the same rating scale and standards for acceptable answers.

Lecturers/Student perceptions of BL were investigated using a structured interview. Statements in the interview's check-list were categorized into three main domains. The first 8 items identified the lecturers'/students' perception of BL process. This was followed with 6 items that identified the perception of the content. The remaining 5 items were related to the domain of lecturers/students' perceived ease of use of technologies available. The scoring for the questions was established following the five point Likert scale: strongly agree $=5$, up to strongly disagree $=1$. The interviews lasted from 20 to 30 minutes. Questions were divided into three sections: knowledge and experience of blended learning, and evaluation of the use of blended learning according to the three main domains of BL process, content, and ease of use. Finally, interviewees were given the opportunity to add further comments.

Data collection included structured interviews with ten academic staff members and 40 undergraduate students who were enrolled in different courses, in particular the field training course. The course was required for every student in the faculty of business regardless of their majors. Students answered the questions based on the usage and perceptions of their learning experience with blended learning. All of these courses were offered at the Faculty of Business at Al-Balqa Applied University with Al-Balqa Electronic Academy, which applied the blended learning approach using traditional F2F learning and e-learning. Due to confidential scientific policy, names of the respondents could not be mentioned.

A primary analysis was carried out which highlighted specific questions relating to views on blended learning and attitudes towards technology. During the next step, written records were then reviewed by the researcher and grouped according to common themes based on their perceptions to identifying similarities and differences amongst participants. According to Benson et al., (2011), this approach has some limitation according to the objectivity and generalizability; nevertheless, it permits a deep and detailed perception regarding the contemporary views and practices of blended learning at the targeted institution.

A test-retest reliability method was used to test the stability and reliability of an instrument over time. Participants were independently interviewed over a period of no more than three weeks. In other words, give the same test twice to the same people at different times to see if the scores are the same. The reliability of the measure across this period was high.

\section{A Blended Learning: Case Study at the Faculty of Business in Al-Balqa Applied University}

The Faculty of Business at Al-Balqa Applied University is a public, four-year program offering bachelor's degrees in the following majors: Business Administration, Accounting, Informational Accounting Systems, Economics, Finance, Management Information Systems, Planning and Project Management, and Marketing. BAU in its effort to achieve its vision to become a scientifically leading and globally competing applied university, distinguished in creativity, innovation, applied scientific research and leadership for the purpose of compounding knowledge economy and society. BAU has recently become interested in BL and opened Al-Balqa Electronic Academy for the purpose of developing and teaching blended learning in the curriculum of electronics. The faculty of business cooperates with Al-Balqa academy in teaching numerous courses, in particular, the field training courses for the eight specialist that offered by the faculty in bachelor's degree. Students will be trained on work skills relevant to their specialization. The training program is designed by instructors in the designated departments and in coordination with Al-Balqa Electronic Academy in accordance with the curricula determined by Al-Balqa Applied University through the use of the ODOO and SAP-ERP Enterprise Resource Planning System software that provides an assortment of business applications that make up a complete collection of enterprise management applications for companies of all sizes, including website/e-commerce, billing, accounting, manufacturing, warehouse, project management, and supply chain management.

With the above mentioned in mind, it is beneficial to briefly re-examine the condition of blended learning in Jordan. Blended learning is suitable for Jordan as BL is appropriately flexible with an educational system the likes of the kingdom, it can complement F2F learning, and it makes distance learning possible. Consequently, many are convinced that BL provides students and staff with a good platform for the latest and most effective teaching and learning system known today.

\section{Analysis and Results}

Table (1-3) present the perception of students and lecturers regarding the following factors of process, content, 
and ease of use in using BL respectively that facilitate or hinder adoption and implementation of blended learning at the faculty of business at Al-Balqa Applied University. In sum, this study presents some interesting views on blended learning provided by student and lecturers. The majority of students and lecturers believe that when it comes to providing for all the needs and learning opportunities required by different specializations, blending learning offers the satisfaction and flexibility that goes beyond the restrictions of time and place.

BL is more convenient than face to face learning from the lecturers' point-of-view, since they are capable of providing information on-demand and instant access to material and explanations for their courses from wherever and whenever their students choose. In addition, another benefit was the ability to easily track students' accessibility and achievements throughout a course. Also, students and lecturers believe that BL is an effective learning tool. Moreover, students have the support of lecturers when it comes to implementing online learning activities and using of interactive forms of e-learning with $\mathrm{F} 2 \mathrm{~F}$ approach.

Table 1 show that students moderately agreed that the traditional F2F approach offers a better learning experience than e-learning and the majority of them disagreed with replacing the F2F approach with e-learning materials for all of their lectures. The results are in agreement with the literature reporting that learning in the Arab culture, to a large level, it is still a physical activity and the individuals who recognize the effectiveness of internet, and who have high technological innovativeness, will be agreeable to a complete e-learning trial period in the Arab world (Al-Busaidi, 2013; Al-Shboul et al., 2013; Saadeh \& Al-Karimi, 2009). According to Saadeh and Al-Karimi, (2009), students have not even considered online resources as an alternative to the F2F approach.

With respect to the perception of BL process as shown in Table 1, lectures perceived BL to be more useful and effective than traditional F2F approach. The majority of lectures/students indicated they enjoyed learning in this modality since it is an effective, interesting and useful learning tool. Table $(1,2)$ show that the majority of the respondents expressed their positive perceptions toward blended learning for their courses. This confirms the findings of a number of researchers that learners showed positive attitudes towards BL (Ja'ashan, 2015). In addition, this reflects the interaction between lectures and students, which save time and effort to do their tasks.

Also, the students' participants suggested using more video conference lectures with business people to create interesting debates. According to Fearon et al., (2011), using teleconferencing to bring together remote speakers from industry and academia for a given keynote lecture or seminar event can be used as a blended learning tool that will actively develop new skill sets for graduates. Students recognize that advance technology is the future, so they are looking for more opportunities of learning that help them to improve their skills and their educational outcomes.

Table 1. Lectures/students 'perceptions of blended learning process

\begin{tabular}{|c|c|c|c|c|c|c|c|c|c|c|c|}
\hline \multicolumn{6}{|c|}{ Students' perceptions } & \multicolumn{6}{|c|}{ Lectures' perceptions } \\
\hline $\begin{array}{l}\text { Strongly } \\
\text { Disagree }\end{array}$ & Disagree & Neutral & Agree & $\begin{array}{l}\text { Strongly } \\
\text { Agree }\end{array}$ & $\begin{array}{l}\text { Mean } \\
\text { Score }\end{array}$ & $\begin{array}{l}\text { Strongly } \\
\text { Disagree }\end{array}$ & Disagree & Neutral & Agree & $\begin{array}{l}\text { Strongly } \\
\text { Agree }\end{array}$ & $\begin{array}{l}\text { Mean } \\
\text { Score }\end{array}$ \\
\hline \multicolumn{12}{|c|}{ Blended learning is an alternative to F2F approach. } \\
\hline 13 & 11 & 8 & 5 & 3 & \multirow{2}{*}{2.35} & 2 & 3 & 2 & 2 & 1 & \multirow{2}{*}{2.7} \\
\hline $32.5 \%$ & $27.5 \%$ & $20 \%$ & $12.5 \%$ & $7.5 \%$ & & $20 \%$ & $30 \%$ & $20 \%$ & $20 \%$ & $10 \%$ & \\
\hline \multicolumn{12}{|c|}{ Blended Learning application is more useful than F2F approach. } \\
\hline 3 & 3 & 28 & 3 & 3 & \multirow{2}{*}{3} & 1 & 1 & 2 & 3 & 3 & \multirow{2}{*}{3.6} \\
\hline $7.5 \%$ & $7.5 \%$ & $70 \%$ & $7.5 \%$ & $7.5 \%$ & & $10 \%$ & $10 \%$ & $20 \%$ & $30 \%$ & $30 \%$ & \\
\hline \multicolumn{12}{|c|}{ Applications of blended learning save time and effort. } \\
\hline 4 & 6 & 8 & 12 & 10 & \multirow{2}{*}{3.45} & 1 & 1 & 1 & 4 & 3 & \multirow{2}{*}{3.3} \\
\hline $10 \%$ & $15 \%$ & $20 \%$ & $30 \%$ & $25 \%$ & & $10 \%$ & $10 \%$ & $10 \%$ & $40 \%$ & $30 \%$ & \\
\hline \multicolumn{12}{|c|}{ Blended Learning has a significant role in the technical development. } \\
\hline 3 & 7 & 7 & 13 & 10 & \multirow{2}{*}{3.5} & - & 1 & 1 & 5 & 3 & \multirow{2}{*}{4} \\
\hline $7.5 \%$ & $17.5 \%$ & $17.5 \%$ & $32.5 \%$ & $25 \%$ & & $0 \%$ & $10 \%$ & $10 \%$ & $50 \%$ & $30 \%$ & \\
\hline \multicolumn{12}{|c|}{ BL enhance the interactive between teachers and students. } \\
\hline 4 & 6 & 7 & 14 & 9 & \multirow{2}{*}{3.45} & 1 & 1 & 2 & 3 & 3 & \multirow{2}{*}{3.6} \\
\hline $10 \%$ & $15 \%$ & $17.5 \%$ & $35 \%$ & $22.5 \%$ & & $10 \%$ & $10 \%$ & $20 \%$ & $30 \%$ & $30 \%$ & \\
\hline \multicolumn{12}{|c|}{ Blended learning is an effective learning tool. } \\
\hline 3 & 5 & 8 & 14 & 10 & \multirow{2}{*}{3.57} & 1 & 1 & 1 & 4 & 3 & \multirow{2}{*}{3.7} \\
\hline $7.5 \%$ & $12.5 \%$ & $20 \%$ & $35 \%$ & $25 \%$ & & $10 \%$ & $10 \%$ & $10 \%$ & $40 \%$ & $30 \%$ & \\
\hline \multicolumn{12}{|c|}{$B L$ are interesting and useful. } \\
\hline 3 & 7 & 9 & 11 & 10 & \multirow{2}{*}{3.45} & 1 & 2 & 2 & 3 & 2 & \multirow{2}{*}{3.3} \\
\hline $7.5 \%$ & $17.5 \%$ & $22.5 \%$ & $27.5 \%$ & $25 \%$ & & $10 \%$ & $20 \%$ & $20 \%$ & $30 \%$ & $20 \%$ & \\
\hline \multicolumn{12}{|c|}{ Blended learning enhances the quality of education. } \\
\hline 2 & 6 & 8 & 14 & 10 & \multirow{2}{*}{3.6} & - & 1 & 1 & 5 & 3 & \multirow{2}{*}{4} \\
\hline $5 \%$ & $15 \%$ & $20 \%$ & $35 \%$ & $25 \%$ & & $0 \%$ & $10 \%$ & $10 \%$ & $50 \%$ & $30 \%$ & \\
\hline
\end{tabular}


From the structured interviewees gathered, Table 2 indicates that the majority of the lectures and students found the $\mathrm{BL}$ content provided better understanding of the subject. BL materials are both interesting and engaging which improved education to the best, since BL content affords the flexibility to learn successfully. These results are the same as the findings of Shantakumari and Sajith, (2015) that show that the online content was well illustrated and easy to understand.

The median scores of all the questions according to the lectures/students 'perceptions of Blended Learning content were above three suggesting positive perceptions on BL. Both academics and students find that blended learning gives greater flexibility for student learning in terms of learning style and study pace. Students clarified that F2F interaction with lectures is important since they need reassurance and on-going support from them. These results resemble what Hussin et al., (2009) found which is that student involvement and course content are among the most satisfactory factors for instructional design principles.

The industrial environment of Jordan is not fully aware of SAP ERP system as it is very expansive to implement and customize. Therefore, the students don't find a solid environment in which they are able to apply the knowledge they gained from learning SAP ERP due to the lack of companies that use the system. Lecturers confirmed that they face a lot of overwork, most of the e-learning platforms they encountered are strict and not flexible, this adds many extra hours of preparing, posting and replying to students enquires. Also, many students complained about the technological complexity they face when submitting or retrieving information using the e-learning platform.

Table 2. Lectures/students "perceptions of blended learning content

\begin{tabular}{|c|c|c|c|c|c|c|c|c|c|c|c|}
\hline \multicolumn{6}{|c|}{ Students' perceptions } & \multicolumn{6}{|c|}{ Lectures' perceptions } \\
\hline Strongly & Disagree & Neutral & Agree & Strongly & Mean & Strongly & Disagree & Neutral & Agree & Strongly & Mean \\
\hline Disagree & & & & Agree & Score & Disagree & & & & Agree & Score \\
\hline \multicolumn{12}{|c|}{ Blended learning content has provided better understanding of the subject. } \\
\hline 4 & 5 & 7 & 14 & 10 & 3.525 & 1 & 1 & 1 & 4 & 3 & 3.4 \\
\hline $10 \%$ & $12.5 \%$ & $17.5 \%$ & $35 \%$ & $25 \%$ & & $10 \%$ & $10 \%$ & $10 \%$ & $40 \%$ & $30 \%$ & \\
\hline \multicolumn{12}{|c|}{ E-learning approach offers a better learning experience than Traditional F2F approach. } \\
\hline 3 & 6 & 22 & 6 & 3 & 3 & 0 & 2 & 2 & 4 & 2 & 3.6 \\
\hline $7.5 \%$ & $15 \%$ & $55 \%$ & $15 \%$ & $7.5 \%$ & & $0 \%$ & $20 \%$ & $20 \%$ & $40 \%$ & $20 \%$ & \\
\hline \multicolumn{12}{|c|}{ BL application layout is not attractive. } \\
\hline 5 & 8 & 7 & 9 & 11 & 3.325 & 1 & 2 & 2 & 3 & 2 & 3.3 \\
\hline $12.5 \%$ & $20 \%$ & $17.5 \%$ & $22.5 \%$ & $27.5 \%$ & & $10 \%$ & $20 \%$ & $20 \%$ & $30 \%$ & $10 \%$ & \\
\hline \multicolumn{12}{|c|}{ Blended Learning with its applications improved education to the best. } \\
\hline 4 & 6 & 8 & 13 & 9 & 3.425 & - & 1 & 2 & 4 & 3 & 3.9 \\
\hline $10 \%$ & $15 \%$ & $20 \%$ & $32.5 \%$ & $22.5 \%$ & & $0 \%$ & $10 \%$ & $20 \%$ & $40 \%$ & $30 \%$ & \\
\hline \multicolumn{12}{|c|}{ The BL materials are both interesting and engaging. } \\
\hline 5 & 8 & 10 & 11 & 6 & 3.125 & 1 & 2 & 2 & 3 & 2 & 3.3 \\
\hline $12.5 \%$ & $20 \%$ & $25 \%$ & $27.5 \%$ & $15 \%$ & & $10 \%$ & $20 \%$ & $20 \%$ & $30 \%$ & $20 \%$ & \\
\hline \multicolumn{12}{|c|}{ BL content affords the flexibility to learn successfully. } \\
\hline 3 & 5 & 7 & 15 & 10 & 3.6 & - & 1 & 2 & 4 & 3 & 3.9 \\
\hline $7.5 \%$ & $12.5 \%$ & $17.5 \%$ & $37.5 \%$ & $25 \%$ & & $0 \%$ & $10 \%$ & $20 \%$ & $40 \%$ & $30 \%$ & \\
\hline
\end{tabular}

Access to technology is one of the most significant factors influencing respondent satisfaction. Table 3 indicates that there are some negative perceptions towards blended learning ease of use from the viewpoints of lectures and students. They indicated that technical difficulties, such as BL instructions' aren't easy to follow, frustrating to use, and slow internet connectivity are prevalent, and they need further support to address them as they lack the technical skills. In the same line, Shantakumari and Sajith, (2015) clarified that not only should the equipment be reliable but also the students should be familiar with its usage. Also, Ja'ashan, (2015) found a negative point as the materials of BL aren't well organized. This reflects also instructions of BL aren't easy to follow.

According to Aldosemani et al., (2019) training for faculty lectures and students should be offered on a continual basis through workshops with the main topics of instructional design, content creation, and student assessment to improve their confidence and skills to equip them with blended teaching skills. New skill sets may be required by staff and students from basic information technology (IT) skills to learning new ways of interacting (Harris et 
al., 2009).

Table 3. Lectures/students 'perceptions of blended learning ease of use

\begin{tabular}{|c|c|c|c|c|c|c|c|c|c|c|c|}
\hline \multicolumn{6}{|c|}{ Students' perceptions } & \multicolumn{6}{|c|}{ Lectures' perceptions } \\
\hline $\begin{array}{l}\text { Strongly } \\
\text { Disagree }\end{array}$ & Disagree & Neutral & Agree & $\begin{array}{l}\text { Strongly } \\
\text { Agree }\end{array}$ & $\begin{array}{l}\text { Mean } \\
\text { Score }\end{array}$ & $\begin{array}{l}\text { Strongly } \\
\text { Disagree }\end{array}$ & Disagree & Neutral & Agree & $\begin{array}{l}\text { Strongly } \\
\text { Agree }\end{array}$ & $\begin{array}{l}\text { Mean } \\
\text { Score }\end{array}$ \\
\hline \multicolumn{12}{|c|}{ Slow internet connectivity is a problem for $B L$} \\
\hline 4 & 5 & 7 & 14 & 10 & \multirow{2}{*}{3.525} & 1 & 1 & 2 & 3 & 3 & \multirow{2}{*}{3.6} \\
\hline $10 \%$ & $12.5 \%$ & $17.5 \%$ & $35 \%$ & $25 \%$ & & $10 \%$ & $10 \%$ & $20 \%$ & $30 \%$ & $30 \%$ & \\
\hline \multicolumn{12}{|c|}{ BL instructions' aren't easy to follow } \\
\hline 4 & 6 & 7 & 13 & 10 & \multirow{2}{*}{3.475} & 1 & 2 & 2 & 3 & 2 & \multirow{2}{*}{3.3} \\
\hline $10 \%$ & $15 \%$ & $17.5 \%$ & $32.5 \%$ & $25 \%$ & & $10 \%$ & $20 \%$ & $20 \%$ & $30 \%$ & $20 \%$ & \\
\hline \multicolumn{12}{|c|}{ Technical difficulties make the online component of blended teaching frustrating } \\
\hline 4 & 5 & 7 & 14 & 10 & \multirow{2}{*}{3.525} & 1 & 1 & 2 & 3 & 3 & \multirow{2}{*}{3.6} \\
\hline $10 \%$ & $12.5 \%$ & $17.5 \%$ & $35 \%$ & $25 \%$ & & $10 \%$ & $10 \%$ & $20 \%$ & $30 \%$ & $30 \%$ & \\
\hline \multicolumn{12}{|c|}{ Blended Learning applications are, hardly, challenging for use. } \\
\hline 3 & 6 & 6 & 15 & 10 & \multirow{2}{*}{3.575} & 1 & 1 & 1 & 4 & 3 & \multirow{2}{*}{3.7} \\
\hline $7.5 \%$ & $15 \%$ & $15 \%$ & $37.5 \%$ & $25 \%$ & & $10 \%$ & $10 \%$ & $10 \%$ & $40 \%$ & $30 \%$ & \\
\hline \multicolumn{12}{|c|}{ Blended Learning applications and tools are hard to be learnt and understand. } \\
\hline 3 & 6 & 6 & 15 & 10 & \multirow{2}{*}{3.575} & 1 & 1 & 1 & 4 & 3 & \multirow{2}{*}{3.7} \\
\hline $7.5 \%$ & $15 \%$ & $15 \%$ & $37.5 \%$ & $25 \%$ & & $10 \%$ & $10 \%$ & $10 \%$ & $40 \%$ & $30 \%$ & \\
\hline
\end{tabular}

\section{Conclusions and Recommendations}

This study concludes that generally both lectures and students 'perceptions towards BL applications are positive in terms of BL process and contents domains in the structured interviews. Furthermore, it concludes that BL is effective in enhancing and improving knowledge and skills which enhances the quality of education in Jordan, specifically in the faculty of business at Al-Balqa Applied University.

According to the interviewees knowledge and experience of blended learning, and evaluation of the use of blended learning according to the three main domains of BL process, content, and ease of use, BL should be implemented as a modern teaching and learning strategy that assists graduates in overcoming the main challenges of working in the next century, since the current era is characterized by rapid changes resulting from scientific and technological advances (Oweis, 2018). Business graduates should be leaving university with a solid collaborative blended learning skill that they learned, as well of thinking that the syllabus they studied would be used in their real world experiences (Fearon et al., 2011; Saleem, 2017).

It is worth to mention that BL is still in the developmental phase in Al-Balqa Applied University. So, educator and policy makers in the university, particularly in the faculty of business requisite to take the unique preferences of lectures/students into consideration while designing and implementing blended application. They should be appropriately informed about the blended component and that their comments and worries should be assuaged thru communication, and training. According to Shantakumari and Sajith, (2015), the content of BL format has to be tailored in line with the course objectives in order to ensure that the course outcomes are met, and the course is well-received by the students. Though many issues arose in the application process, the initial findings proved that the BL approach could be expanded to include all of the courses in the faculty of business and to all courses of Al-Balqa Applied University.

In addition, both lecturers and students face technical inexperience which made them feel uncomfortable with using e-learning tools. SAP's data model is very complex and challenging to be understood by undergraduates who don't have any real business experience, which will cause problems with data analysis, add to that understanding the technology that supports the system is not easy as they will focus on how to use the system, rather than understanding the business process itself. Accordingly, both lecturers and students may be required to prepare more for such a course.

For researchers and practitioners throughout the Arab world, and particularly in Jordan, this study offers several suggestions. This study encourages the higher education authorities and the educational institutions in Jordan to focus on its technological infrastructure - a major requirement of the blended learning method. Also, this research has provided valuable and very explicit insight into the areas that need improvement for student 
experience together with the Jordanian University's formal methods for gathering and responding to the feedback of students.

One of the advantages of blended learning is that lecturers and students will be aware of and used to different approaches of teaching and learning. This would be so helpful in different urgent situations where face to face teaching and learning would be impossible. In such cases the process of learning and teaching would only follow one approach which is online learning. This would not be new to students and lecturers nor challenging since it is part of the approach they are already following. With the ongoing global spread of coronavirus, COVID-19, the universities which were following the approach of blended learning (F2F and online learning) are the only ones which were successfully able to continue the process of teaching whereas other universities are challenging with online teaching. After Corona, BL approach will still remain an important approach of learning at many universities, because education lies on the combination of online and offline learning. This means that the use of BL approach will enhance the flexibility of teaching in the universities to be ready to go online when global emergencies appear and then move back to the norm when things blow over.

Hypothetically, the findings of the study add to the growing field of literature about the effective style of learning and especially blending learning and improved upon the idea that technology plays, and will continue to play, a key role to enhance the future of higher education across all levels and disciplines.

This study recommends the following based on the results:

- Recognize the training needs of faculty, staff and students in implementing the use of BL tools as the latest and most effective teaching and learning system platform.

- Enhance systems setup and maintenance, technical research and development and technical support.

- Reconsider the implementation strategies of university programs and incorporate the concept of electronic and technological advancement and the idea of blending them in order to take benefit of resources, not only at a technological level but also at a pedagogical one, namely in reference to community building and collaborative learning opportunities that meet the creativity and innovation requirements which will meet the needs of individuals and society.

- Since, many students complained about the technological complexity they face when submitting or retrieving information using the e-learning platform. Therefore, this study suggests that students should take a comprehensive course in the e-learning platform during the enrollment stage into the university.

\section{Limitation and Recommendation for Future Research}

There were a few limitations to this study. First, this study was conducted at only one university in Jordan. To improve the generalization of this study's results, any future studies should explore more cross-cultural cases at different levels of education, as it is likely that a study at other institutions of higher education may yield different results. Also, to examine the learners' actual use of blended learning, a combination of different research methodologies and longitudinal studies could be used in future research. As a limitation for this study, only qualitative structure interviews tools is employed to collect the data. Therefore, to gain insight about the benefits and significance of blended learning from the students and lecturers point of view, a quantitative tool of the questionnaire survey would be more efficient. Based on a small sample of respondents, this study was inherently limited regarding the significance and generalizability of its findings to the whole institution or Jordan as a whole, so future research should use of a large scale survey by replicate the study by including different institutions in different geographical regions so as to arrive at more generalizable results.

\section{References}

Adas, D., \& Wafa, A. S. (2011). Students' perceptions towards blended learning environment using the OCC, AnNajah Univ. J. Res. (Humanities), 25(6), 1682-1710. Retrieved from https://staff-old.najah.edu/sites/default/files/students039-perceptions-towards-blended-learning-environmen t-using-occ.pdf

Al-Busaidi, K. (2013). An empirical investigation linking learners' adoption of blended learning to their intention of full e-learning. Behaviour \& Information Technology, 32(11), 1168-1176. https://doi.org/10.1080/0144929X.2013.774047

Aldosemani, T., Shepherd, C., \& Bolliger, D. (2019). Perceptions of Instructors Teaching in Saudi Blended Learning Environments. TechTrends, (Preprints), 1-12. https://doi.org/10.1007/s11528-018-0342-1 
Alkış, N., \& Temizel, T. (2018). The Impact of Motivation and Personality on Academic Performance in Online and Blended Learning Environments, Blended Learning Environments. Educational Technology \& Society, 21(3), 35-47. Retrieved from https://www.jstor.org/stable/26458505

Almasi, M., \& Zhu, C. (2018). Students' Perceptions of Social Presence in Blended Learning Courses in a Tanzanian Medical College. International Journal of Emerging Technologies in Learning, 13(9), 107-122. Retrieved from https://www.learntechlib.org/p/184896/

Al-Shboul, M., Rababah, O., Al-Saideh, M., Betawi, I., \& Jabbar, S. (2013). A Vision to Improve E-Learning at the University of Jordan. World Applied Sciences Journal, 21(6), 902-914. https://doi.org/10.5829/idosi.wasj.2013.21.6.227

Arbaugh, J., Desai, A., Rau, B., \& Sridhar, B. (2010). A review of research on online and blended learning in the management disciplines: 1994-2009. Organization Management Journal, 7(1), 39-55. Retrieved from https://doi.org/10.1057/omj.2010.5

Aristovnik, A., Keržič, D., Tomaževič, N., \& Umek, L. (2016). Demographic determinants of usefulness of e-learning tools among students of public administration. Interactive Technology and Smart Education, 13(4), 289-304. https://doi.org/10.1108/ITSE-09-2016-0033

Bayrak, T., \& Akcam, B. (2017). Understanding student perceptions of a web-based blended learning environment. Journal of Applied Research in Higher Education, 9(4), 577-597. https://doi.org/10.1108/JARHE-12-2016-0090

Benson, V., Anderson, D., \& Ooms, A. (2011). Educators' perceptions, attitudes and practices: blended learning in business and management education. Research in Learning Technology, 19(2), 143-154. https://doi.org/10.3402/rlt.v19i2.10353

Bentley, Y., Selassie, H., \& Parkin, E. (2012). Evaluation of a global blended learning MBA programme. The International Journal of Management Education, 10, 75-87. http://hdl.handle.net/10547/244256

Bunt-Kokhuis, S., \& Weir D. (2013). Serving culturally diverse e-learners in business schools. Multicultural Education \& Technology Journal, 7(1), 17-45. https://doi.org/10.1108/17504971311312609

Cundell, A. \& Sheepy, E. (2018). Student perceptions of the most effective and engaging online learning activities in a blended graduate seminar. Online Learning, 22(3), 87-102. http://dx.doi.org/10.24059/olj.v22i3.1467

Dana, L.P. \& Dana, T.E. (2005). Expanding the scope of methodologies used in entrepreneurship research. Int. J. Entrepreneurship and Small Business, 2(1), 79-88. http://dx.doi.org/10.1504/IJESB.2005.006071

Fearon, C., Starr, S., \& McLaughlin H. (2011). Value of blended learning in university and the workplace: some experiences of university students. Industrial and Commercial Training, 43(7), 446-450. https://doi.org/10.1108/00197851111171872

Fearon, C., Starr, S., \& McLaughlin H. (2012). Blended learning in higher education (HE): conceptualizing key strategic issues within a business school. Development and Learning in Organizations: An International Journal, 26(2), 19-22. https://doi.org/10.1108/14777281211201196

Harris, P., Connolly, J., \& Feeney, L. (2009). Blended learning: overview and recommendations for successful implementation. Industrial and Commercial Training, 41(3), 155-163. https://doi.org/10.1108/00197850910950961

Hussin, H., Bunyarit, F., \& Hussein R. (2009). Instructional design and e-learning: Examining learners' perspective in Malaysian institutions of higher learning. Campus-Wide Information Systems, 26(1), 4-19. https://doi.org/10.1108/10650740910921537

Inal, M. \& Korkmaz, Ö. (2019). The effect of web based blended learning on students' academic achievement and attitudes towards English course. Education and Information Technologies. https://doi.org/10.1007/s10639-019-09890-7

Ja'ashan, Mohammed. (2015). Perceptions and Attitudes towards Blended Learning for English Courses: A Case Study of Students at University of Bisha. English Language Teaching, 8(9), 40-50. http://dx.doi.org/10.5539/elt.v8n9p40

Kintu, M., Zhu, Chang., \& Kagambe, E. (2017). Blended learning effectiveness: the relationship between student characteristics, design features and outcomes. International Journal of Educational Technology in Higher Education, 14(1), 1-20. https://doi.org/10.1186/s41239-017-0043-4 
Lam, J., Hung, A., Chan, F., Yan, K., \& Woo, G. (2011). Project management model for blended learning course development. International Journal of Continuing Education and Lifelong Learning, 4(1), 107-122. Retrieved from https://search.informit.com.au/documentSummary; $\mathrm{dn}=755115088168038 ;$;res=IELHSS

Magnier-Watanabe, R., Benton, C., Herrig, H., \& Aba, O. (2011). Blended learning in MBA education: a cross-cultural experiment. Open Learning, 26(3), 253-263. https://doi.org/10.1080/02680513.2011.611686

Medina, L. (2018). Blended learning: Deficits and prospects in higher education. Australasian Journal of Educational Technology, 34(1), 42-56. https://doi.org/10.14742/ajet.3100

Neira, E., Salinas, J., \& Crosetti, B. (2017). Emerging Technologies (ETs) in Education: A Systematic Review of the Literature Published between 2006 and 2016. Journal of Emerging Technologies in Learning, 13(10), 158-170. Retrieved from http://hdl.handle.net/11201/149593

Nguyen V. (2017). Towards the implementation of an assessment-centred blended learning framework at the course level: A case study in a Vietnamese national university. The International Journal of Information and Learning Technology, 34(1), 20-30. https://doi.org/10.1108/IJILT-08-2016-0031

Nortvig, A. M., Petersen, A. K., \& Balle, S. H. (2018). A Literature Review of the Factors Influencing ELearning and Blended Learning in Relation to Learning Outcome, Student Satisfaction and Engagement. The Electronic Journal of e-Learning, 16(1), 46-55. Retrieved from https://eric.ed.gov/?id=EJ1175336

Obiedat, R., Nasir Eddeen, L., Harfoushi, O., Koury, A., AL-Hamarsheh, M., \& AlAssaf, N. (2014). Effect of Blended-Learning on Academic Achievement of Students in the University of Jordan. International Journal of Emerging Technologies in Learning, 9(2), 37-44. Retrieved from DOI: 10.3991/ijet. v9i2.3220

Oiry, E. (2009). Electronic human resource management: organizational responses to role conflicts created by e-learning. International Journal of Training and Development, 13(2), 111-123. https://doi.org/10.1111/j.1468-2419.2009.00321.x

Oweis, T. (2018). Effects of Using a Blended Learning Method on Students' Achievement and Motivation to Learn English in Jordan: A Pilot Case Study. Education Research International, 1-7. https://doi.org/10.1155/2018/7425924

Perera, M., Johar, G., Kathibi, A., Atan, H., Abeysekera, N., \& Dharmaratne, I. (2017). PLS-SEM Based Analysis of Service Quality and Satisfaction in Open Distance Learning in Sri Lanka. International Journal of Business and Management, 12(11), 194-217. https://doi.org/10.5539/ijbm.v12n11p194

Poon, Joanna. (2012). Use of blended learning to enhance the student learning experience and engagement in property education. Property Management, 30(2), 129-156. https://doi.org/10.1108/02637471211213398

Saadeh, D., \& Al-Karimi, Q. (2009). Blended e-learning Approach at the University of Jordan. In the Proceedings of the International Conference on Information Technology, 60-66. Retrieved from https://www.zuj.edu.jo/conferences/ICIT09/PaperList/Papers/Distance\%20Learning\%20and\%20E-educatio n/505.pdf

Saleem, T. (2017). The effect of using blended learning method on the achievement of students at Al-Balqa Applied University-Jordan. International Journal of Instructional Technology and Distance Learning, 14(6), 3-19. Retrieved from http://www.itdl.org/Journal/Jun_17/Jun17.pdf

Sekaran, and Bougie, R. (2016). Research methods for business a skill-building approach. West Sussex, United Kingdom: John Wiley and Sons.

Shantakumari, N., \& Sajith, P. (2015). Blended Learning: The Student Viewpoint. Annals of Medical \& Health Sciences Research, 5(5), 323-328. Retrieved from https://dx.doi.org/10.4103\%2F2141-9248.165248

Thomas, M., \& Thomas H. (2012). Using new social media and Web 2.0 technologies in business school teaching and learning. Journal of Management Development, 31(4), 358-367. https://doi.org/10.1108/02621711211219013

Tso, A. (2015). Reflections on Blended Learning: A Case Study at the Open University of Hong Kong. Asian Association of Open Universities Journal, 10(1), 77-86. https://doi.org/10.1108/AAOUJ-10-01-2015-B008

Uğur, B., Akkoyunlu, B. \& Kurbanoğlu, S. (2011). Students' opinions on blended learning and its implementation in terms of their learning style. Education and Information Technologies, 16(1), 5-23. https://doi.org/10.1007/s10639-009-9109-9 
Wong, L., Tatnall, A. and Burgess, S. (2014). A framework for investigating blended learning effectiveness. Education + Training, 56(2/3), 233-251. https://doi.org/10.1108/ET-04-2013-0049

Yin, R., \& Campbell, D. (2018). Case study research and applications: design and methods. Thousand Oaks, California: SAGE Publications, Inc.

Zainol, Z. (2018). Digital Disruption in Higher Learning Education: The Implementation of Blended Learning for Undergraduates. Global Business and Management Research: An International Journal, 10(3), 579-588. Retrieved from https://www.questia.com/library/journal/1G1-567634625/digital-disruption-in-higher-learning-education-th e

Zhang, J. (2018). Blended Learning Innovation Model among College Students Based on Internet. Journal of Emerging Technologies in Learning, 13(10), 158-170. Retrieved from https://online-journals.org/index.php/i-jet/article/view/9454

\section{Copyrights}

Copyright for this article is retained by the author(s), with first publication rights granted to the journal.

This is an open-access article distributed under the terms and conditions of the Creative Commons Attribution license (http://creativecommons.org/licenses/by/4.0/). 